\title{
MEASURING STUDENT'S LOGICAL REASONING SKILLS OF CHINESE SENIOR HIGH SCHOOL USING RASCH MEASUREMENT MODEL
}

\author{
Lijuan Gan ${ }^{1)}$, Tommy Tanu Wijaya ${ }^{2)}$ \\ 1) Department Mathematics and Statistics, Guangxi Normal University, China \\ 2) School of Mathematics Sciences, Beijing Normal University, China \\ Email: 2589028396@qq.com
}

\begin{abstract}
Abstrak
Penelitian ini bertujuan untuk mengembangkan alat evaluasi untuk mengevaluasi keseluruhan keterampilan core literasi penalaran logis dan memahami perbedaan tingkat literasi penalaran logis antara siswa dari kelas yang berbeda dan jenis kelamin yang berbeda. Kualitas alat evaluasi yang dikembangkan diuji dan dioptimalkan berdasarkan model Rasch. Data sampel yang diukur diproses dan dianalisis dengan perangkat lunak winsteps dan perangkat lunak SPSS. 122 siswa kelas 3 SMA dari kelas yang berbeda dievaluasi dengan alat evaluasi tingkat literasi penalaran logis yang dikembangkan dengan reliabilitas dan validitas yang baik. Ditemukan bahwa keseluruhan literasi penalaran logis siswa SMA terkonsentrasi di Level II, dan beberapa siswa bisa mencapai Level III; terlihat jelas perbedaan tingkat literasi penalaran logis antara kelas eksperimen dan kelas biasa. Tingkat keseluruhan kelas eksperimen lebih tinggi dari kelas biasa; ada sedikit perbedaan distribusi anak laki-laki dan perempuan di tingkat rendah, tetapi dibandingkan dengan anak laki-laki, tingkat melek huruf anak perempuan jelas terbatas setelah mencapai tingkat tertentu, sehingga sulit untuk menerobos dan naik ke tingkat ketiga.
\end{abstract}

Kata kunci-Mathematics core literacy; Rasch Model; Assessment tools; logical reasoning skills.

\begin{abstract}
This study aims to develop an evaluation tool to evaluate the overall logical reasoning core literacy skill and understand the differences in logical reasoning skills between students of different classes and genders. The quality of the developed evaluation tool is tested and optimized based on the Rasch model. The measured sample data are processed and analyzed by winsteps software and SPSS software. 122 senior three students from different classes were evaluated by the developed logical reasoning literacy level evaluation tool with good reliability and validity. It was found that the overall logical reasoning skills of senior high school students was concentrated in Level II, and some students could reach Level III; there are obvious differences in the level of logical reasoning skills between the experimental class and the ordinary class. The overall level of the experimental class is higher than that of the ordinary class; there is little difference in the distribution of male and female at the low level, but compared with male, female' literacy Level Is obviously limited after reaching a certain level, so it is difficult to break through and rise to the third level.
\end{abstract}

Keywords - Mathematics core literacy; Rasch model; Assessment tools; logical reasoning skills.

\section{INTRODUCTION}

With the advent of a knowledge-based economic society with globalization and informatization, training students to deal with a challenging and uncertain future society has become the main direction of international education reform. In recent years, international organizations and countries worldwide have also paid great attention to developing students' mathematical literacy and improving students' reasoning ability (Bernhardt et al., 2014; Nikou \& Aavakare, 2021). For example, the 2021 Program for International Student Assessment (PISA) has adjusted "mathematical reasoning" in the definition and expression of mathematical literacy, it emphasizes the core position of mathematical logical reasoning skills in problem solving and mathematical literacy, and increases the scoring weight of mathematical logical reasoning skills to $25 \%$, indicating that PISA2021 attaches great importance to logical reasoning skills (Ma \& Qin, 2021). PISA2021 Project is an international student literacy evaluation project involving nearly 100 countries and regions around the world. Therefore, PISA2021 logical reasoning skills is an important ability requirement of the times and the international community, and it is the core ability that talents should have in the 21 st century. 
ISSN. 2621-9832

JURNAL MathEdu (Mathematic Education Journal) http://journal.ipts.ac.id/index.php/MathEdu Vol. 4 No. 3 November 2021

Logical reasoning skills are a basic form of thinking in mathematics and often used in people's study and life (Chotimah et al., 2020; Zhang \& Qi, 2019). PISA2021 framework divides mathematical reasoning into deductive reasoning and inductive reasoning. Among them, deductive reasoning is the process of deriving other conclusions through deduction from the general premise, highlighting the reasoning from general to special; Inductive reasoning also includes analogy and induction, which is a kind of reasoning based on existing facts and conclusions, or analogy and induction based on statistics and probability to obtain new conclusions (Ayuningtyas et al., 2019). China's 《Criterion for Curriculum》defines logical reasoning as one of the six core qualities of mathematics and defines the content and different levels of logical reasoning performance. Most studies have proved that, The strength of logical reasoning skills is closely related to the level of mathematics academic achievement, which not only shows the impact of logical reasoning skills on students' achievement but also shows that students' implicit logical reasoning literacy can be evaluated through students' explicit academic achievement (Bayazit, 2013; Bernard \& Chotimah, 2018; Hidayat et al., 2018).

Rasch model is a potential trait model proposed by Danish mathematician and statistician Georg Rasch in 1960 (Weller et al., 2013). It is an important branch of item response theory (Boone \& Staver, 2020). Item response theory is based on a mathematical model and uses item characteristic parameters to estimate the potential traits of the test, it can measure the non directly observable traits through the individual's response to the test questions Potential variables (Sumintono, 2016). Compared with the traditional potential capability test, the project and project characteristic parameters of the project response theory are invariant, while the measurement results of the traditional test often change with the change of the test samples, In addition, the tested characteristics of item response theory and the difficulty of items are defined in the same dimension, and they can be directly compared with each other. In traditional tests, they are not in the same dimension, Can't compare with each other.

Inspired by this, based on the Rasch model, this study developed a special tool to evaluate students' logical reasoning literacy and conducted a limited-time test for senior three students to evaluate the logical reasoning skills level of senior three students after three years of study in senior high school, in order to put forward suggestions on the cultivation of students' logical reasoning skills and provide a reference for the evaluation and research of other literacy dimensions.

\section{METHOD}

Study design

This paper develops an evaluation tool for senior three students' logical reasoning skills by using the paper and pen test method and referring to the division and definition of logical reasoning literacy Level In China's curriculum standard. Combined with Rasch model, the quality of the developed evaluation tool is tested and optimized before using it. This paper attempts to use the evaluation tools to investigate the overall logical reasoning skills level of Senior High School students, and compare and analyze the literacy level of experimental class students and ordinary class students, as well as the differences in logical reasoning literacy level among students of different gender

\section{Instruments}

Referring to the three levels of logical reasoning skills in China's high school curriculum standard and its specific behavior, this study compiled the "logical reasoning skills level evaluation tool". After preparing the evaluation questions, mathematics education experts and high school front-line mathematics teachers were invited to evaluate and analyze the effectiveness and feasibility of the questions. According to their suggestions, the test questions were modified and improved, and then a test was conducted. According to the data analysis results of the preliminary test, the test questions were newly adjusted and modified, a small-scale secondary test was conducted to test the tool, and the final scale of "logic reasoning level evaluation tool for senior three students" was determined. The scale includes 12 multiple-choice questions (A) and 4 blank filling questions (B), The distribution of topics is shown in Table 1: 
JURNAL MathEdu (Mathematic Education Journal) http://journal.ipts.ac.id/index.php/MathEdu Vol. 4 No. 3 November 2021

Tabel 1. matching distribution of logical reasoning skills level and evaluation questions

\begin{tabular}{lc}
\hline Horizontal Distribution & \multicolumn{2}{c}{ Question Matching } \\
\hline Level I: Understanding and Knowing & A1、A3、A5、A7、A10 \\
\hline Level II: Master and Application & A2、A6、A8、A9、B1、B2 \\
\hline Level III: Migration and Creation & A4、A11、A12、B3、B4 \\
\hline
\end{tabular}

Data collection

This study conducted three rounds of students' logical reasoning skills level test. The purpose of the first round of test is to test the effectiveness of the evaluation tools. 25 male and female students in senior three of a demonstration high school in a county in China were selected for the test. The scale was modified and improved according to the measurement results, 40 senior three students from a high school near city were selected for the test. The data analysis results showed that the reliability and validity of the evaluation tool were good, and then the final test was carried out. Finally, an experimental class and a regular class were selected for the final test in a local demonstration high school, and the test sample data were collected, and 122 valid data were obtained through statistics.

Data analysis

Based on the Rasch model, this study encodes the original answers of 122 students and compares the answers Score by two-level scoring, 1 point for correct answer and 0 point for the wrong answer. Process the data with winsteps software and SPSS software to test the reliability and validity of the scale and analyze the students' logical reasoning level.

\section{RESULTS AND DISCUSSION}

Overall quality analysis of evaluation tools

The collected and sorted measurement data of 122 students are analyzed and processed by winsteps software to obtain various parameters about the quality of the scale, as shown in Table 2:

Tabel 2. overall quality statistical results of logical reasoning skills evaluation of senior three students

\begin{tabular}{ccccccccc}
\hline & Measure & Model & \multicolumn{2}{c}{ Infit } & \multicolumn{2}{c}{ Outfit } & Separation & Reliability \\
& S.E. & \multicolumn{2}{c}{ Mnsq Zstd } & \multicolumn{2}{c}{ Mnsq Zstd } & . & \\
\hline Person & .48 & .65 & .99 & .02 & .99 & .18 & 1.13 & .65 \\
\hline Item & .00 & .28 & 1.00 & .05 & .99 & -.09 & 5.27 & .97 \\
\hline
\end{tabular}

It can be seen from the table data that the estimated value of the test item difficulty is 0.00 , and the estimated value of the measured literacy Level Is 0.48 , which is higher than the item difficulty value, indicating that the test scale is relatively simple for the subjects as a whole. The estimated error of the test item difficulty is 0.28 , and the estimated error of the subjects is 0.65 , all within the allowable error range, It shows that the scale is more accurate in estimating students' literacy level and project difficulty. In the measured internal fitting index, MNSQ value is 0.99 and ZSTD value is 0.02 , while in the external fitting index, MNSQ value is 0.99 and ZSTD value is 0.18 ; The MNSQ value in the internal fitting index of the project is 1 , the ZSTD value is 0.05 , the MNSQ value in the external fitting index is 0.99 , and the ZSTD value is -0.9. The internal and external fitting indexes of both are close to the standard value 1 , and the ZSTD value is close to the standard value 0, indicating that the real test data of the scale is in good agreement with the ideal model. The measured separation degree is 1.13 , and the reliability is 0.65 , It shows that the evaluation tool can distinguish students with high and low logical reasoning skills; The separation degree of the items is 5.27 and the reliability is 0.97 , indicating that the number of samples selected is sufficient to determine the logical reasoning skills level of the test questions, and the overall performance of the evaluation tools and test sample data is high.

Wright map is also called tested item correspondence. It places the subject's literacy level and the difficulty of the item on both sides of the logit scale to intuitively show the horizontal comparison relationship between the two. On the left of the logit scale is 122 students, "\#" represents 2 students and "." 
ISSN. 2621-9832

JURNAL MathEdu (Mathematic Education Journal) http://journal.ipts.ac.id/index.php/MathEdu

Vol. 4 No. 3 November 2021

represents 1 student; on the right are 12 multiple-choice questions and 4 blank filling questions of the test scale. Looking from bottom to top on the logit scale, the higher the top represents the stronger the ability of the students distributed on the left, and the more difficult the questions distributed on the right. It can be seen from Figure 1 that the average difficulty $m$ of measuring the test questions is equal to 0 , and the average literacy level of the tested is between 0.4 and 0.5 , the overall logical reasoning skills level of students is higher than the difficulty value of the test questions. The 16 test questions are widely distributed and relatively evenly distributed from the distribution of measurement test questions. Apart from the simple test question $\mathrm{A} 1$, which is lower than the lowest level of students' literacy, the test questions of the evaluation tool cover the students' logical reasoning skills level. The distribution of students' literacy level is relatively concentrated and uniform, and most students' logical reasoning skills Level Is about 0.5, indicating that the tested samples are representative.

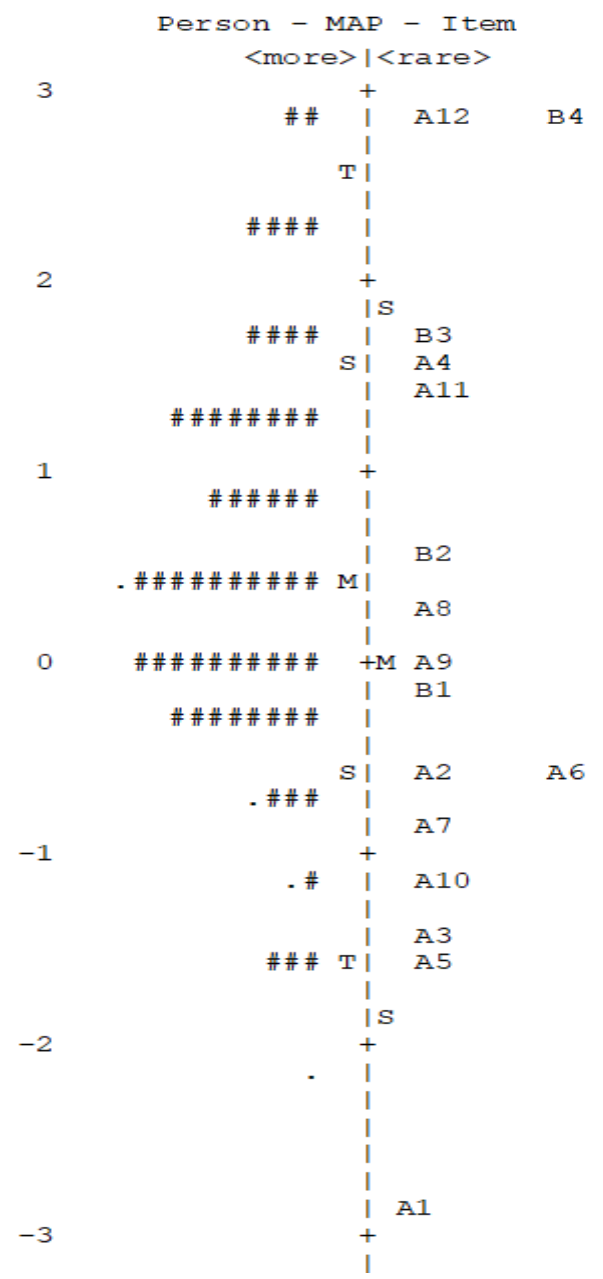

Figure 1. correspondence between the difficulty of test questions and students' logical reasoning skill

Quality analysis of tool test questions

It can be seen from Table 3 that the difficulty range of the 16 test questions is -2.95 to 2.91 . The difficulty range of the test questions is widely distributed and can measure students with different logical reasoning literacy levels. The difficulty of the top-down questions is getting lower and lower, the fourth question of the blank filling question is more difficult, and the first question of the multiple-choice question is too simple. The model standard error of the difficulty value estimation of each question is between 0.20 to 0.41 , Except that the standard error of question A1 exceeds 0.4 , the errors of other questions are within 0.30 , indicating that the measured difficulty value of the question is close to the real value and the data reliability is high. The internal fitting index MNSQ value of the question is between 0.90 to 1.19 , and the ZSTD value is between -1.54 to 1.35 except that B2 is 2.17; The MNSQ value of the external fitting index is between 0.22 and 1.20 except that A12 is 2.42, and the ZSTD value is between -1.66 and 1.71 except that A12 is 3.01, which is basically within the required fitting range. However, the MNSQ value of the internal and external fitting index is better between 0.7 and 1.3, and the ZSTD value is better between - 2 
ISSN. 2621-9832

JURNAL MathEdu (Mathematic Education Journal) http://journal.ipts.ac.id/index.php/MathEdu Vol. 4 No. 3 November 2021

and +2 (Saidi \& Siew, 2019). This shows that the fitting degree between topics A12 and B2 and the data is not good. This is mainly caused by some students' incorrect attitudes towards answering test questions. Except A12, the correlation coefficient of other questions ranges from 0.3 to 0.6 , indicating that the test scale has good discrimination ability and can really measure the level of students' logical reasoning literacy (Ahmad \& Siew, 2021).

Tabel 3. parameter statistics of all test questions in the evaluation tool

\begin{tabular}{cccccccc}
\hline \multirow{2}{*}{ ITEM } & \multirow{2}{*}{ MEASURE } & \multirow{2}{*}{ MODEL } & \multicolumn{2}{c}{ INFIT } & \multicolumn{2}{c}{ OUTFIT } & \multirow{2}{*}{ PTMEA } \\
\cline { 5 - 7 } & & S.E. & MNSQ & ZSTD & MNSQ & ZSTD & \\
\hline B4 & 2.91 & .30 & .98 & -.05 & .99 & .10 & .31 \\
\hline A12 & 2.82 & .29 & 1.19 & .99 & 2.42 & 2.01 & .17 \\
\hline B3 & 1.67 & .22 & 1.03 & .34 & 1.11 & .67 & .37 \\
\hline A4 & 1.53 & .22 & .95 & -.42 & .89 & -.60 & .45 \\
\hline A11 & 1.39 & .21 & 1.09 & .90 & 1.07 & .51 & .34 \\
\hline B2 & .51 & .20 & 1.17 & 2.17 & 1.19 & 1.71 & .28 \\
\hline A8 & .22 & .20 & .90 & -1.43 & .85 & -1.42 & .52 \\
\hline A9 & -.06 & .20 & .88 & -1.54 & .80 & -1.66 & .52 \\
\hline B1 & -.10 & .20 & 1.11 & 1.35 & 1.08 & .68 & .32 \\
\hline A2 & -.54 & .21 & .92 & -.82 & .80 & -1.26 & .48 \\
\hline A6 & -.59 & .22 & .91 & -.90 & .77 & -1.38 & .48 \\
\hline A7 & -.83 & .23 & 1.00 & .07 & 1.20 & 1.00 & .34 \\
\hline A10 & -1.10 & .24 & 1.00 & .06 & .79 & -.88 & .39 \\
\hline A3 & -1.40 & .26 & 1.02 & .15 & .93 & -.17 & .32 \\
\hline A5 & -1.61 & .27 & .93 & -.37 & .67 & -1.06 & .40 \\
\hline A1 & -2.95 & .41 & .97 & .29 & .22 & -.71 & .18 \\
\hline & & & & & & & \\
\hline
\end{tabular}

Through the overall quality analysis of evaluation tools and the quality analysis of tool test questions, the results show that the evaluation tool in this study has good reliability and validity, that is, the test tool can accurately and effectively evaluate the level of logical reasoning literacy of junior and senior three students.

Analysis of students' logical reasoning skills

The average difficulty of the test questions and the number of people at each level of logical reasoning literacy are shown in Table 4 . The difficulty range of Level I is -2.95 to -0.83 , and the average value is -1.578 ; the difficulty range of Level II is -0.59 to 0.51 , and the average value is -0.093 ; the difficulty range of Level III is 1.39 to 2.91 , and the average value is 2.064 . That is, when the student's ability value is lower than -1.578 , the student's logical reasoning literacy does not reach Level I, and when the student's ability value is between -1.578 to -0.093 , the student's logical reasoning literacy reaches Level I; When the students' ability value is between -0.093 and 2.064, the students' logical reasoning literacy reaches Level II; When the student's ability value is higher than 2.064, the student's logical reasoning literacy reaches Level III. From the proportion of each level of literacy, senior three students' overall logical reasoning literacy is in Level II, $10 \%$ of the students' logical reasoning literacy reaches Level III, and a small part of the students' literacy is relatively low. However, the level of students' logical reasoning literacy is still relatively high on the whole. This may be related to the selected school. The school is a demonstration high school in a thirdtier city with a relatively developed economic level, so the educational facilities, equipment and teacher resources are relatively good, and the students' learning conditions are excellent, The resources and conditions have opened up students' horizons and thinking to a certain extent, making students receive higher education quality and remarkable learning effect. 
ISSN. 2621-9832

JURNAL MathEdu (Mathematic Education Journal) http://journal.ipts.ac.id/index.php/MathEdu

Vol. 4 No. 3 November 2021

Tabel 4. average difficulty of test questions at all levels of logical reasoning skills and proportion of people

\begin{tabular}{cccc}
\hline $\begin{array}{c}\text { Literacy } \\
\text { Level }\end{array}$ & Corresponding Questions & $\begin{array}{c}\text { Average } \\
\text { Difficulty }\end{array}$ & $\begin{array}{c}\text { Proportion } \\
\text { Number }\end{array}$ \\
\hline Level I & A1、A3、A5、A7、A10 & -1.578 & $32(26 \%)$ \\
Level II & A2、A6、A8、A9、 & 0.093 & $77(63 \%)$ \\
B1、B2 & & $12(10 \%)$ \\
\hline
\end{tabular}

Note: one student's ability value is between -2.2 to -2.1 , which is lower than the literacy

Level I

Table 5 shows the distribution of students' logical reasoning literacy between the experimental class and the ordinary class. Most of the students in the experimental class have logical reasoning literacy at Level II or above, which shows that the students in the experimental class are at a relatively high level as a whole, and the distribution is relatively concentrated. While the logical reasoning literacy of students in the ordinary class accounts for $42 \%$ at Level I and $52.9 \%$ at Level II, It shows that the literacy level of ordinary class students is concentrated in Level I and Level II, and the overall literacy of the class still has much room to improve. In conclusion, it shows that the logical reasoning literacy of experimental class students is significantly different from that of ordinary class students, and the level of logical reasoning literacy is relatively low. This may be caused by the differences in students' knowledge base in different classes and the differences in class modes. Generally, the experimental class is composed of students with better academic performance than the ordinary class. Their knowledge base is relatively solid. They are less affected by the restriction of knowledge reserve in logical reasoning; In addition, the classroom teaching of the ordinary class generally emphasizes the memory of knowledge points and does not have high requirements for understanding and proof. The experimental class pays more attention to allowing students to think independently and driving students to explore and discover through problems. Students' logical reasoning ability has been developed and trained to a certain extent in this learning process.

Tabel 5. number and proportion of students with different literacy levels in different classes

\begin{tabular}{cccccc}
\hline & $\begin{array}{c}\text { Total } \\
\text { Mumber }\end{array}$ & $\begin{array}{c}\text { Lower than } \\
\text { Literacy Level } \\
\text { I }\end{array}$ & $\begin{array}{c}\text { Literacy } \\
\text { Level } \\
\text { I }\end{array}$ & $\begin{array}{c}\text { Literacy } \\
\text { Level } \\
\text { II }\end{array}$ & $\begin{array}{c}\text { Literacy } \\
\text { Level } \\
\text { III }\end{array}$ \\
\hline $\begin{array}{c}\text { Experimental } \\
\text { Class }\end{array}$ & $54(100 \%)$ & $0(0 \%)$ & $3(5.6 \%)$ & $41(75.9 \%)$ & $10(18.5 \%)$ \\
\hline Ordinary Class & $68(100 \%)$ & $1(1.5 \%)$ & $29(42.6 \%)$ & $36(52.9 \%)$ & $2(2.9 \%)$ \\
\hline
\end{tabular}

Table 6 shows the distribution of male' and female' logical reasoning literacy levels. From the table data, it can be seen that the distribution of male' logical reasoning literacy levels is symmetrical and concentrated in Level II; There is little difference between Level I and Level III, but there is a certain proportion, indicating that the level of male' logical reasoning literacy is polarized. While female' logical reasoning literacy accounts for a large proportion in Level I and Level II, only $6.8 \%$ of female are at Level III, and one girl's logical reasoning literacy is lower than Level I, It shows that the overall logical reasoning literacy of female is at a relatively low Level I and Level II, female' logical reasoning literacy will be limited after reaching a certain level, It is difficult to break through to the third level.. Combined with the previous analysis and the characteristics that the proportion of male in Level II and Level III is more significant than that of female, it can be seen that male students have a greater advantage than female students in logical reasoning ability, and the overall level of male is higher than that of female. This may be related to the 
personality traits between men and women, the structure of left and right brain and the degree of development. Although the differences between men and women in physiological structure lead to the differences in the level of logical reasoning literacy between men and women, schools and teachers can not ignore the impact of education on the development of logical reasoning ability, so there should be no gender discrimination in the study of Arts and Sciences.

Table 6. number and proportion of students of different gender and literacy levels

\begin{tabular}{lccccc}
\hline & Total & $\begin{array}{c}\text { Lower than } \\
\text { Literacy Level I }\end{array}$ & $\begin{array}{c}\text { Literacy Level } \\
\text { I }\end{array}$ & $\begin{array}{c}\text { Literacy Level } \\
\text { II }\end{array}$ & $\begin{array}{c}\text { Literacy Level } \\
\text { III }\end{array}$ \\
\hline Male & $63(100 \%)$ & $0(0 \%)$ & $11(17.5 \%)$ & $44(69.8 \%)$ & $8(12.7 \%)$ \\
\hline Female & $59(100 \%)$ & $1(1.7 \%)$ & $21(35.6 \%)$ & $33(55.9 \%)$ & $4(6.8 \%)$ \\
\hline
\end{tabular}

\section{CONCLUSION}

Although the logical reasoning literacy evaluation tool used this time has good identification ability and can accurately measure students at different levels of reasoning ability, it can be seen from the white chart that the upper difficult test questions in the evaluation tool span a large range and lack test questions matching the ability of upper middle school students, so that the reasoning ability value of each student can not be measured more finely, Some test questions should be added before the subsequent evaluation research using the tool. The original low and medium difficulty test questions and high-energy difficulty test questions can be transformed and split. The low and medium difficulty test questions are increased by 1-2 difficulty levels respectively, and the high difficulty test questions are disassembled into 1-2 medium and high difficulty questions, so as to refine the measurement unit of the evaluation tool, Enhance the consistency between the evaluation tools and students' literacy level, and improve the accuracy of measurement results. In addition, although this study understands that basic knowledge, teaching mode and gender differences are the factors causing different levels of students' logical reasoning ability, there should also be undiscovered key influencing factors. The follow-up evaluation research can be carried out from the perspectives of different economic levels, regions, stages and grades, family income and parental education, Carry out comparative research on students' logical reasoning literacy level under different factors, and explore the factors affecting the development of students' logical reasoning literacy level. Finally, although through evaluation and quantitative research, we can understand the level of students' logical reasoning literacy under different conditions and backgrounds, and find some laws and phenomena, However, there is insufficient explanation for the causes of the phenomenon and the strategies and ways to eliminate the adverse phenomenon, so the follow-up needs to pay attention to qualitative research. For example, combined with the latest research results of brain neuroscience, it reveals the scientific reasons for the significant differences in the level of logical reasoning literacy between different sexes.

\section{ACKNOWLEDGMENTS}

I would like to thank Guangxi Normal University. Research on the consistency between the mathematics test and the curriculum standard of the college entrance examination under the core literacy perspective (Innovation Project of Guangxi Graduate Education 2021, NO.YCSW2021102).

\section{REFERENCES}

Ahmad, J., \& Siew, N. M. (2021). Curiosity towards stem education: A questionnaire for primary school students. Journal of Baltic Science Education, 20(2), 289-304. https://doi.org/10.33225/jbse/21.20.289

Ayuningtyas, W., Mardiyana, \& Pramudya, I. (2019). Students' responses to the test instruments on geometry reasoning ability in senior high school. Journal of Physics: Conference Series, 1265(1). https://doi.org/10.1088/1742-6596/1265/1/012015

Bayazit, I. (2013). Quality of the Tasks in the New Turkish Elementary Mathematics Textbooks: the Case of Proportional Reasoning. International Journal of Science and Mathematics Education, 11(3), 651682. https://doi.org/10.1007/s10763-012-9358-8

Bernard, M., \& Chotimah, S. (2018). Improve student mathematical reasoning ability with open-ended approach using VBA for powerpoint. AIP Conference Proceedings, 2014(September). 
https://doi.org/10.1063/1.5054417

Bernhardt, A. C., Yorozu, R., \& Medel-Añonuevo, C. (2014). Literacy and life skills education for vulnerable youth: What policy makers can do. International Review of Education, 60(2), 279-288. https://doi.org/10.1007/s11159-014-9419-z

Boone, W. J., \& Staver, J. R. (2020). Advances in Rasch Analyses in the Human Sciences. Springer International Publishing AG.

Chotimah, S., Wijaya, T. T., Aprianti, E., Akbar, P., \& Bernard, M. (2020). Increasing primary school students ' reasoning ability on the topic of plane geometry by using hawgent dynamic mathematics software. Journal of Physics: Conference Series, 1657(1), 012009. https://doi.org/10.1088/1742$6596 / 1657 / 1 / 012009$

Hidayat, W., Wahyudin, W., \& Prabawanto, S. (2018). Improving students' creative mathematical reasoning ability students through adversity quotient and argument driven inquiry learning. Journal of Physics: Conference Series, 948(1). https://doi.org/https://doi.org/10.1088/17426596/948/1/012005

Ma, Y., \& Qin, X. (2021). Measurement invariance of information, communication and technology (ICT) engagement and its relationship with student academic literacy: Evidence from PISA 2018. Studies in Educational Evaluation, 68(January), 100982. https://doi.org/10.1016/j.stueduc.2021.100982

Nikou, S., \& Aavakare, M. (2021). An assessment of the interplay between literacy and digital Technology in Higher Education. Education and Information Technologies. https://doi.org/10.1007/s10639-02110451-0

Saidi, S. S., \& Siew, N. M. (2019). Reliability and Validity Analysis of Statistical Reasoning Test Survey Instrument using the Rasch Measurement Model. International Electronic Journal of Mathematics Education, 14(3), 535-546. https://doi.org/10.29333/iejme/5755

Sumintono, B. (2016). Aplikasi pemodelan Rasch pada asesmen pendidikan: Implementasi penilaian formatif (Assessment for learning). Makalah Dipresentasikan Dalam Kuliah Umum Pada Jurusan Statistika, Institut Teknologi Sepuluh November, Surabaya, 17 Maret 2016., March, 1-19. http://eprints.um.edu.my/15876/1/ITS_rasch_model_asesment_for_learning.pdf

Weller, J. A., Dieckmann, N. F., Tusler, M., Mertz, C. K., Burns, W. J., \& Peters, E. (2013). Development and Testing of an Abbreviated Numeracy Scale: A Rasch Analysis Approach. Journal of Behavioral Decision Making, 26(2), 198-212. https://doi.org/10.1002/bdm.1751

Zhang, D., \& Qi, C. (2019). Reasoning and proof in eighth-grade mathematics textbooks in China. International Journal of Educational Research, 98(September), 77-90. https://doi.org/10.1016/j.ijer.2019.08.015 